\title{
Corporate Governance and Disclosure Practices in Listed Information Technology (IT) Companies in India
}

\author{
M. Subramanyam ${ }^{1}$, Himachalam Dasaraju² \\ ${ }^{1}$ REVA School of Commerce, REVA University, Bangalore, India \\ ${ }^{2}$ REVA School of Commerce, Faculty of Commerce \& Management, REVA University, Bangalore, India \\ Email: drmutyala2013@gmail.com, dhchalam@gmail.com
}

Received 18 July 2014; revised 27 August 2014; accepted 17 September 2014

Copyright (C) 2014 by authors and Scientific Research Publishing Inc.

This work is licensed under the Creative Commons Attribution International License (CC BY). http://creativecommons.org/licenses/by/4.0/

(c) (i) Open Access

\begin{abstract}
Manuscript Type: Empirical. Research Question/Issue: The present paper attempts to analyze the level of disclosure on corporate governance practices among the biggest IT companies in India (in terms of exports as per Electronics and Computer Software Export Promotion Council (ESC) in the time period 2004-2005 to 2011-2012 and its effects on performance and profitability. Research Findings/Results: Using the survey of 6 IT companies with the Standard \& Poor's score card to assess the corporate governance disclosure practices of the companies as a benchmark. It is observed that among the sample IT companies, Infosys, Wipro, TCS and HCL scored high score i.e. more than 100 and Tech Mahindra and Mphasis scored low score i.e. less than 96 in corporate governance disclosure practices. Theoretical Implications: The results of the study support theoretical arguments that corporate governance disclosure increases performance. Practical Implications: A country's government environment-especially legal and market infrastructure-highly affect the companies' rate of disclosure which then increases profitability. To policy makers and practitioners, the results suggest that corporate governance should be monitored. Good legislation and a market environment that is free from corruption are essential for corporate governance disclosure to be efficient.
\end{abstract}

\section{Keywords}

Corporate Governance Disclosure Practices, Information Technology, Listed Companies and Transparency and Disclosure UNCTAD

\section{Introduction}

Corporate governance is about maintaining an appropriate balance of accountability between three key players:

How to cite this paper: Subramanyam, M. and Dasaraju, H. (2014) Corporate Governance and Disclosure Practices in Listed Information Technology (IT) Companies in India. Open Journal of Accounting, 3, 89-106. 
the corporation's owners, the directors whom the owners elect, and the managers whom the directors select. Accountability requires not only good transparency, but also an effective means to take action for poor performance or bad decisions.

(Mary L. Schapiro, Chairperson, Securities and Exchange Commission, USA, Address to Transatlantic Corporate Governance Dialogue-September 17, 2009)

Traditionally the main medium for communicating Corporate Governance (CG) practices has been though company annual reports. The internet now provides an additional communication tool to augment traditional corporate reporting practices. Internationally, web-based communication has been promoted to enhance traditional communication practices by "enabling equitable access to information for all interested stakeholders. Corporate disclosure is a process through which a corporate entity communicates business and financial information to their stakeholders. A strong, informative and transparent system of corporate disclosure is of paramount importance for the efficient and effective allocation of resources as well as integrity of financial markets. High-quality corporate disclosure helps investors and other capital market participants by enabling them to make proper assessment of the potential risks and rewards of alternative investments. Well-informed investment decision-making by capital market participants leads to efficient allocation of capital, which promotes productivity and economic growth.

With more and more business organisations attaining a global edge and expanding in size; and with more retail and institutional investors entering into capital markets, the corporate disclosure practices have assumed added importance in the recent past. Led by these changes, companies listed on stock exchange have been forced to disclose the minimum information in their annual reports as set out by the statutory requirements. However, particularly large and publicly traded leading companies have gone beyond those minimum requirements. Reporting information voluntarily has become a norm for large companies. In fact, a large proportion of corporate disclosures made through annual reporting concern an agenda of visualising the company's core values, mission statement, business concept, and social responsibility.

This suggests that annual reporting plays a central role in legitimising the company's existence. Of all the forms or ways of corporate disclosure, corporate annual report is the most important, vital and popular source of information in the arena of the corporate world and investment market which is a focal point of corporate disclosure mechanism. Annual report today is not simply a means of communication; it is now being used as a vehicle of building and enhancing corporate image. Considering the limited scope, a humble attempt is hereby made to study on the corporate governance disclosure practices in annual reports of some selected listed IT companies in India with an objective to form a bird's eye view on the emerging scenario of corporate disclosure practices in India.

A strong disclosure regime is a pivotal feature of market-based monitoring of corporate conduct and is central to the ability of shareholders to exercise their voting rights effectively. Experience in countries with large and active equity markets shows that disclosure can also be a powerful tool for influencing the behaviour of companies and for protecting investors. A strong disclosure regime can help to attract capital and maintain confidence in capital markets. Shareholders and potential investors require access to regular, reliable and comparable information in sufficient detail for them to assess the stewardship of management and make informed decisions about the valuation, ownership and voting of shares. Insufficient or unclear information may hamper the ability of markets to function, may increase the cost of capital and result in a poor allocation of resources.

Disclosure also helps improve public understanding of the structure and activities of companies, their policies and performance with respect to environmental and ethical standards and their relationships with the communities in which they operate. Disclosure practice does not develop in a vacuum, but rather reflects the underlying environmental influences that affect managers and companies in different countries [1].

\section{Corporate Governance Disclosure Standards in Vogue}

Timely disclosure of accurate information on important firm-related matters is crucial for the protection of shareholders' rights for two main reasons. First, shareholders need to have access to information about important matters to make decisions that are in their interests. Second, information disclosure is crucial in preventing managers and dominant shareholders from engaging in activities that are illegal or are detrimental to minority shareholders. Managers and dominant shareholders will be more reluctant to undertake such activities when they expect that shareholders will find out about them and may take action against them. Managers and dominant 
shareholders will also run the risk of violating laws when they fail to disclose information about such activities. Before the crisis, information disclosure was deemed to be incomplete and seriously flawed in the world. The countries in the world wide had initiated a range of reform measures to improve information disclosed to shareholders and to the general public. The reform measures adopted by the East Asian countries since the economic crisis encompass the auditing process, the timing of disclosure and the types of information that must be disclosed.

During the 1990s, a number of high-profile corporate scandals in the USA (viz., Lehman Brothers, AIG Insurance, Xerox, Arthur Anderson, Enron, WorldCom, Tyco, satyam, etc.), and also elsewhere in the world, triggered an in-depth reflection on the regulatory role of the government in protecting the interests of shareholders. Thus, to redress the problem of corporate misconduct, ensuring "sound" CG is believed to be essential to maintaining investors' confidence and good performance. In view of the growing number of scandals and the subsequent wide-spread public and media outcry, a plethora of governance "norms", "codes", "best practices", and "standards" have sprouted around the globe. For instance, the Sarbanes-Oxley Legislation in the USA, the Cadbury Committee recommendations for the European Union (EU) companies, and the Organisation for Economic Co-operation and Development (OECD) principles of corporate governance, are perhaps the best-known among these. The Cadbury Committee (1992) [2] advocated, first of all, disclosure as "a mechanism for accountability, emphasizing the need to raise reporting standards in order to ward-off the threat of regulation. Improved disclosure results in improved transparency, which is one of the most essential elements of healthy CG practices". Similarly, the Hampel Committee (1998) [3] regulated disclosure as "the most important element of accountability and in introducing a new code and set of principles stated that their objective was not to prescribe corporate behaviour in detail but to secure sufficient disclosure so that investors and others can assess companies' performance and governance practice and respond in an informed way". According to the OECD's (2006) [4] "Guidance on Good Practices in Corporate Governance Disclosure", "All material issues relating to CG of the enterprise should be disclosed in a timely fashion. The disclosure should be clear, concise, precise, and governed by the substance over form principle”.

Communication via corporate disclosure is self-evidently a very important aspect of CG in the sense that meaningful and adequate disclosure enhances good CG. For instance, Whittington (1993) [5] lucidly states: "Published annual reports are used as a medium for communicating both quantitative and qualitative corporate information to shareholders, potential shareholders (investors) and other users". Although publication of an annual report is a statutory requirement, companies normally disclose information voluntarily in excess of the mandatory requirements. Company management recognizes that there are economic benefits to be gained from a well-managed disclosure policy. However, the UNCTD "Guidance on Good Practices in Corporate Governance Disclosure (2006) [6]" succinctly describes: "The location of CG disclosures within the Annual Report of a Corporation is not generally well-defined and can vary substantially across-country in practice. However, some degree of harmonization of the location of CG disclosures would be desirable to make the relevant data more accessible, in the long-run". Two possible approaches include: first, putting all CG disclosures in a "Separate Section" of the Annual Report and second, in a stand-alone "Corporate Governance Report". Examples of the former approach are found in the recommendations of the Hong Kong Society of Accountants, and the listing requirements in India and Switzerland, which provide for CG disclosures to appear in a "separate section" of the Annual Report and in a prescribed format. Similarly, the OECD's "Guidance on Good Practices in CG Disclosure (2006)" forcefully suggests that "where CG disclosures are not consolidated, there should be sufficient cross-referencing to different disclosures so as to improve access to the information". Even where disclosure requirements exist, there is usually substantial latitude afforded to managers in relation to the quality and quantity of disclosure about company-specific governance practices [7]. Moreover, the enterprise should disclose awards or accolades for its good CG practices, especially where such awards or recognition come from "independent” international agencies.

In the years following the Asian crisis of 1997, there has been considerable pressure placed on the Asian companies to improve their CG. This has included calls for improved transparency, stronger external monitoring, and heightened investor protection [8]. However, rather than taking a regulatory approach (such as the SarbanesOxley Act in the U.S.), Asian countries have implemented "voluntary" CG Codes, advising Companies as to how to improve their governance and disclosure practices. Over the last few years, the thinking on the CG topic in India has gradually "crystallized" into the development of norms for listed companies. To quote the words of 
Sareen (2009), "The codes, while not mandatory, do encourage Companies to implement stronger CG structures, and release more information in a timely manner to market participants". The current requirements for disclosures of CG [9] practices in India have developed from a reform process that began in the late 1990s. In fact, there have been several CG initiatives launched in India since the mid-1990s. The first was by the Confederation of Indian Industry (CII), which came up with the "first” Voluntary Code of CG in 1998 [10]. The second was by the "Securities Exchange Board of India [11]," now enshrined as Clause 49 of the Listing Agreement. The third was the Naresh Chandra Committee, which submitted its report in 2002. The fourth was again by SEBI the Narayana Murthy Committee, which also submitted its report in 2002. Based on some of the recommendations of these two committees, SEBI revised Clause 49 of the Listing Agreement in August 2003. Unfortunately, the problem for private companies, which form a vast majority of Indian corporate entities, remains largely unaddressed. It should be noted here that even the most prudent norms can be hoodwinked in a system plagued with widespread corruption [12]. Nevertheless, with industry organizations and chambers of commerce themselves pushing for an improved CG system, the future of CG in India promises to be distinctly better than the past.

\section{Clause 49 of the Listing Agreement}

The term "Clause 49" refers to clause number 49 of the Listing Agreement between a company and the Stock Exchanges on which it is listed. The Listing Agreement is identical for all Indian Stock Exchanges, including the NSE and BSE. This clause is a recent addition to the Listing Agreement and was inserted as late as 2000 consequent to the recommendations of the Kumar Mangalam Birla Committee on CG constituted by SEBI in 1999. Clause 49, when it was first added, was intended to introduce some basic CG practices in Indian companies and bring in a number of key changes in governance and disclosures. In late 2002, the SEBI constituted the Narayana Murthy Committee to "assess the adequacy of current corporate governance practices and to suggest improvements". Based on the recommendations of this committee, SEBI issued a modified Clause 49 on October 29, 2004 (the "revised Clause 49") which came into operation on 1st January, 2006.

Revised Clause 49 of the Listing Agreement in India requires all listed companies to file every quarter a CG report. According to SEBI guidelines (visit www.sebi.gov.in), "The key mandatory features of Clause 49 regulations deal with the followings: composition of the board of directors, the composition and functioning of the audit committee, governance and disclosures regarding subsidiary companies, disclosures by the company, CEO/CFO certification of financial results and reporting on CG as part of the Annual Report". Moreover, Clause 49 also requires companies to provide "specific" corporate disclosures of the followings: related-party transactions, disclosure of accounting treatment if deviating from Accounting Standards, risk management procedures, proceeds from various kinds of share issues, remuneration of directors, a management discussion and analysis section in the annual report discussing general business conditions, outlook and background and committee memberships of new directors, as well as, presentations to analysts. In addition, a board committee, with a non-executive chair, is required to address shareholder or investor grievances. Finally, share transfer, a longstanding problem in India, must be done expeditiously [13].

The revised Clause 49 has suitably pushed forward the original intent of protecting the interests of investors through enhanced governance practices and disclosures. The revised Clause 49 moves further into the realm of global best practices (and sometimes, even beyond). In this connection, Chakrabarti (2008) very aptly commented as: "Similar in spirit and scope to the Sarbanes-Oxley measures in the USA, Clause 49 has clearly been a milestone in the evolution of CG practices in India”. It is now mandatory for the Indian listed companies to file with the SEBI, the CG compliance report, shareholding pattern along with the financial statements. The SEBI has created a separate link, known as "Edifar", to post the relevant information submitted by the company. No doubt, the quality and quantity of disclosures have improved [14].

\section{Transparency and Disclosure}

India's listed companies get strong marks for following the legal mandate fairly strict standards of governance and disclosure, particularly compared to neighbors. Comparisons show that the standards are far stronger than all other Asian countries, and in general stronger than most OECD countries. Indian corporate sector regulators and companies have been quick to accept some of the best practices for international governance and disclosure. Indian companies have made significant progress with good quarterly reporting standards that improved the dis- 
tribution of timely data. Information technology has made possible easy dissemination of information about listed companies and market intermediaries. Equity research and analysis and credit rating have improved the quality of information. The SEBI has a system for Electronic Data Information Filing and Retrieval System (EDIFAR) to facilitate electronic filing of public domain information by companies. The trend of presentations to analysts is also positive. Also, it observes that the governance practices are strong in companies with listings in overseas markets and those with high credit quality. Still, more training is crucial for directors, including independent directors, audit committee members and senior executives of companies. The challenge is to design and sustain a system that imbibes the spirit of corporate governance and not merely the letter of the law. There is also a need to improve the quality, timeliness and ease of access to information for all stakeholders. Further, the disclosures need improvement in terms of facilitating increased shareholder participation at meetings.

\section{The Role of Disclosure in Improving Corporate Governance}

Why should one care about the disclosure of governance practices? The bottom line, after many years of debate and study, is that good corporate governance benefits companies, investors and markets. Governance practices affect company performance and are an important element in analysts' evaluations of risk both for individual companies and for markets. From the perspective of policy makers, better corporate governance has the potential to enhance the efficiency of companies and markets, reduce the cost of capital and encourage innovation. In short, corporate governance is essentially crucial.

Disclosure is important because reporting is widely viewed as the most effective tool that regulators have to encourage better corporate governance. Reporting puts information in the hands of the markets. And markets and investors make investment decisions based on this information. The markets function best when they have access to sufficient information to properly assess governance. Good information helps the markets ascertain the degree to which companies respond to shareholder needs; it reveals risks, and shows the quality of future cash flows.

\section{Review of Literature}

In this section an attempt is made to review various studies carried out by the experts in India and International.

Standard \& Poor's (2004) [15] study assessed the disclosures regarding corporate governance practices among the largest listed companies in Indonesia, Singapore, Malaysia, Thailand and Hongkong using the score card developed by Standard \& Poor's. It highlighted the companies with highest standards of disclosures on their corporate governance practices. For instance and objective comparison, the study focused only on annual report disclosure. They found considerable variation among the sample companies and finally they compared the disclosure practices with top five companies in each of the country.

Bala N. Balasubramanian (2009) [16] studied the corporate governance practices of firms in India prior to clause 49 of listing agreement made mandatory to all listed companies. He provided a detailed overview of the practices of publicly traded firms in India, and identified areas where governance practices are relatively strong or weak. Also he examined whether there is a cross-sectional relationship between measures of governance and measures of firm performance and found evidence of a positive relationship for an overall governance index and for an index covering shareholder rights. The association is stronger for more profitable firms and firms with stronger growth opportunities.

Bernard S. Black (2009) [17] examined the corporate governance practices of Brazilian public companies to identify areas where their governance is relatively strong and weak. Many firms have small boards, comprised entirely or almost entirely of insiders or representatives of the controlling family or group. Even some very large firms have no independent directors. Formal board processes are limited. Audit committees are uncommon. But many firms use a substitute body to the fiscal board which does not demand that the firm have independent directors to staff the audit committee.

Sanjay P. S. Dessai and Dr. I. Bhanumurthy (2010) [18] in their study made an attempt to evaluate the corporate governance and disclosure practices followed by 30 SENSEX companies by examining the annual reports for financial year which ended by 31st march 2009. The major thrust of this study is on Composition of Board of Directors, Audit Committee and Shareholders Grievance Committee. The study found that corporate governance and disclosure practices followed by SENSEX companies are very good with an exception of just one or two items. 
Arijit Sen (2011) [19] this study sought to determine the extent to which Indian listed companies disclose their corporate governance practices by examining the annual reports of 50 listed companies. Also, the determinants of disclosures have been looked into. They concluded that there is a substantial scope for improvement in the corporate governance disclosure practices and the size of the company is a significant determinant of disclosures.

Swati Patel, Rashesh Patel (2012) [20] attempted to analyze the level of corporate governance norms been adhered to by major IT companies of India as per the guidelines of International Financial Corporation and the Corporate Governance norms of Securities and Exchange Board of India. They tried to develop a conceptual understanding of correlation between various parameters of companies' transparency, disclosures and provided comparative average scores of last three years of performance on a score card adopted. It is an empirical analysis of the corporate governance dimensions of high and low-performing companies with the phase of the research based on the data gathered from the annual report disclosures of the companies. The sample was selected on the basis of Market capitalization for the assessment year 2011-12. The authors found varied levels of differences in disclosures and transparency levels of Indian IT companies. The analysis showcases the fact that different companies have different weight age on parameters analyzed as per Clause 49 of SEBI's listing agreement.

\section{Objectives}

The present study purports to assess the Corporate Governance and disclosure practices in select listed Information Technology (IT) Companies in India. As a part of this inquiry, it furnishes a detailed analysis of the various developments, challenges in Corporate Governance and disclosure practices in Indian context. It also analyses and compares the results with the global studies on similar lines. To be more specific, the prime objectives of the investigation are:

1) To study Corporate Governance practices in IT companies.

2) To dwell upon Corporate Governance disclosure practices in select IT companies in India.

\section{Methodology}

The present study surveys the Corporate Governance and Disclosure practices in Indian Corporate IT sector. For this purpose it makes use of secondary data. The study adopts a two-way approach. First, it focuses on the evolution of CG, its structure, mechanism, regulatory framework, codes of CG and its implementation and so on; secondly, on the sample companies to assess the efficiency of CG and its Disclosures. Further, the study makes a judicious use of the various reports of the Ministry of Corporate Affairs, SEBI and other global agencies. The study involves using the corporate governance disclosure scorecard to rate the corporate governance disclosure practices of the sample companies. The scorecard items reflect principles and best practices embodied in international corporate governance codes.

\section{Tools of Analysis}

The study extensively makes use of the corporate governance disclosure scorecard developed by Standard \& Poor's to assess the corporate governance disclosure practices of the companies. This scorecard consists of 115 items with a maximum score of 129 and was designed to ensure maximum objectivity in assessing the companies. The scorecard items reflect principles and best practices embodied in international corporate governance codes, suitably modified for the Indian environment. The data collected (secondary data) was classified, calculated, tabulated and analysed using appropriate tools such as percentages, One-way ANOVA.

\section{Corporate Governance Disclosures Practices in Sample IT Companies by Using Score Card}

The importance of good corporate governance is now widely recognized, with many studies demonstrating that companies with such a characteristic can attract higher stock price premiums and thus achieve better long-term performance. The Asian financial crisis in 1997 and the recent global corporate scandals, such as those involving Enron, Worldcom, Parmalat and Satyam, have highlighted the importance of good corporate governance for the long-term survival of companies. 
This study assesses the disclosures regarding corporate governance practices among the sample IT listed companies in India, using a scorecard developed by Standard \& Poor's. It highlights the Indian companies with the highest standards of disclosures on their corporate governance practices and the areas that they excel in and also areas where other companies fall short relatives to their peers.

While this study focuses on disclosures, it does not endeavor to assess the quality of the information provided or identify any disclosure that may be incorrect or fraudulent. For consistent and objective comparison, this study focuses only on annual report disclosure; it does not include the different types of company disclosure that may exist. For example, company Web sites and other types of reports may provide additional information relevant to stakeholders. The disclosure items contained in the Indian scorecard were tailored to create more differentiation among the companies on the Straits Times Index (STI) than would have resulted, had we used the original Standard \& Poor's scorecard.

It should also be noted that while the disclosure items contained in the scorecard represent key components of corporate governance, the individual company scores derived from this study are not proxies for corporate governance assessments. Thorough corporate governance assessments require a more flexible and qualitative analytical approach. Standard \& Poor's interactive corporate governance scoring service is a much more detailed and in-depth analysis of the corporate governance practices of companies that have an interest in a more thorough diagnostic. Despite these limitations, the results of this study enable valuable benchmarking and reveal some interesting findings that can help companies develop a clear road map for further improvement.

The method applied here for evaluation of the standard and quality of corporate governance practiced in the sample IT companies has considered all the relevant conditions of corporate governance stipulated by Clause 49 of the Listing Agreement as well as the provisions of the companies Act, 1956. In order to ascertain how far these companies are complying of governance standard, a score card has been employed which developed by Standard \& Poors, whereby an adequate weight age in terms of score has been provided to these conditions according to their importance. It helps to pinpoint the quality and effectiveness of corporate governance with scores assigned to important parameters of governance. Accordingly, each company has been awarded points on some parameters, which constitute the governance process in that company. The governance parameters are selected on a 129 scores as shown in the Table 1.

It is observed that out of the total 129 scores, 46 scores have been assigned to board related matters namely frequency of the board meetings disclosed, attendance of the board of directors etc., 29 scores assigned to remuneration related matters, 26 to audit related matters, 21 scores to nomination related matters, 5 scores assigned to communication with shareholders and 2 scores to statement of company philosophy on code of governance.

The result of evaluation on corporate governance standards adopted and practiced by all 6 IT companies as disclosed in their annual reports, the governance standards attained by the sample 6 IT companies and the average scores secured by all these listed companies, company wise with respect to the compliance of corporate governance standards are shown in the Table 2.

The Table 2 reveals the corporate governance score card wise sample of the IT companies. It is observed that F value 33.85 is highly insignificant. So the top six IT companies behave very differently with respect to corporate governance. The high values of R-sq is $80 \%$ and it supports that the ANOVA models best suit this data.

Table 1. Selected key governance parameters.

\begin{tabular}{cc}
\hline Governance Parameters & Scores Assigned \\
\hline Statement of Company Philosophy on Code of Governance & 2 \\
Board Matters & 46 \\
Nomination Matters & 21 \\
Remuneration Matters & 29 \\
Audit Matters & 26 \\
Communication with Shareholders & 5 \\
Total & $\mathbf{1 2 9}$ \\
\hline
\end{tabular}


Table 2. Compliance of corporate governance standards, scored card wise sample IT companies.

\begin{tabular}{cccccccc}
\hline Year & TCS & Infosys & Wipro & HCL & Tech M & Mphasis & $\begin{array}{c}\text { Total } \\
\text { Assigned Score }\end{array}$ \\
\hline $2004-05$ & $94(72.87)$ & $114(88.37)$ & $110(85.27)$ & $90(69.77)$ & $85(65.89)$ & $90(69.77)$ & $129(100.00)$ \\
$2005-06$ & $93(72.09)$ & $115(89.15)$ & $101(78.29)$ & $90(69.77)$ & $85(65.89)$ & $85(65.89)$ & $129(100.00)$ \\
$2006-07$ & $107(82.95)$ & $115(89.15)$ & $101(78.29)$ & $90(69.77)$ & $85(65.89)$ & $88(68.22)$ & $129(100.00)$ \\
$2007-08$ & $107(82.95)$ & $114(88.37)$ & $101(78.29)$ & $90(69.77)$ & $85(65.89)$ & $88(68.22)$ & $129(100.00)$ \\
$2008-09$ & $105(81.40)$ & $114(88.37)$ & $109(84.50)$ & $106(82.17)$ & $90(69.77)$ & $90(69.77)$ & $129(100.00)$ \\
$2009-10$ & $108(83.72)$ & $114(88.37)$ & $111(86.50)$ & $109(84.50)$ & $90(69.77)$ & $85(65.89)$ & $129(100.00)$ \\
$2010-11$ & $108(83.72)$ & $114(88.37)$ & $111(86.50)$ & $105(81.40)$ & $90(69.77)$ & $88(68.22)$ & $129(100.00)$ \\
$2011-12$ & $106(82.17)$ & $114(88.37)$ & $111(86.50)$ & $105(81.40)$ & $95(73.64)$ & $88(68.22)$ & $129(100.00)$ \\
\hline
\end{tabular}

Source: Researcher Compilation

One-way ANOVA: TCS, Infosys, Wipro, HCL, Tech M, Mphasis.

\begin{tabular}{ccccc}
\hline Source & DOF & SS & MS & F Value \\
\hline Factor & 5 & 4454.9 & 891.0 & 33.85 \\
Error & 42 & 1105.6 & 26.3 & 0.000 \\
Total & 47 & 5560.5 & & \\
\hline
\end{tabular}

$\mathrm{S}=5.131 \mathrm{R}-\mathrm{Sq}=80.12 \% \mathrm{R}-\mathrm{Sq}(\mathrm{adj})=77.75 \%$.

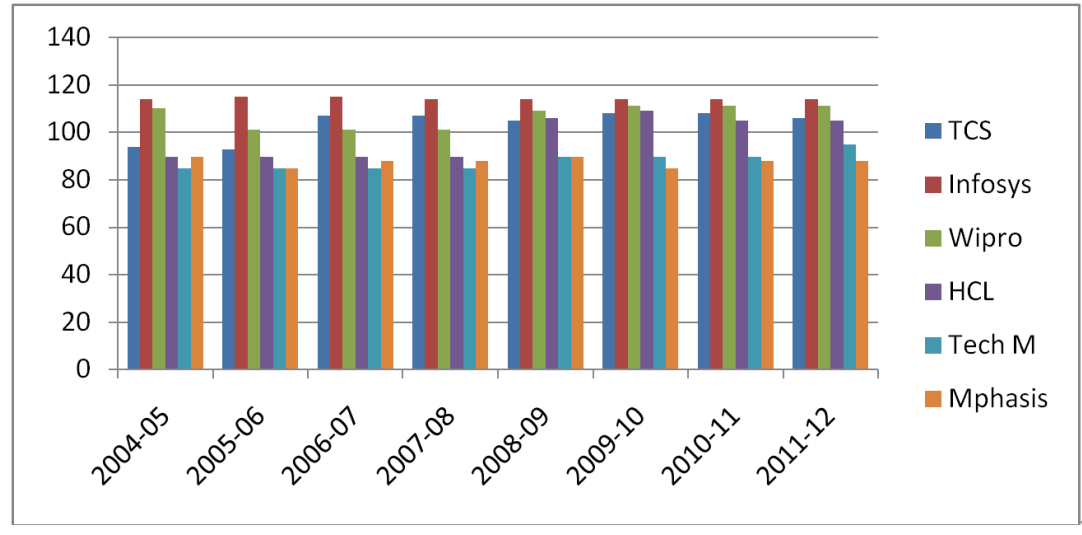

Most of the scores clustered between 85 and 115, which denotes high disclosure standards among the companies in the sample. However, there are some companies with extremely low scores, notably, all except one of the companies with scores below 85. In the year 2004-05 corporate governance disclosures in sample IT companies were 94 (72.87\%), 114 (88.37\%), 110 (85.27\%), 90 (69.27\%), 85 (65.89\%) and 90 (69.77\%) in TCS, Infosys, Wipro, HCL, Tech Mahindra and Mphasis respectively. In this year, it is found that among the sample IT companies Infosys had scored high score i.e. 110 (85.27\%) out of 129 (100.00\%) and tech Mahindra scored only 85 (65.89\%) out of 129 (100.00\%). In the year 2011-12, corporate governance disclosures in sample IT companies were, 106 (82.17\%), 114 (88.37), 111(86.50), 105 (81.40), 95 (73.64) and 88 (68.22) in TCS, Infosys, Wipro, HCL, Tech Mahindra and Mphasis respectively. it is found that. In between the years form 2005-06 to 2010-11 there were plenty of changes taken place in terms of corporate governance disclosure practices in the said sample IT companies. It is observed that the entire sample IT companies gradually improved their disclosure practices in terms of corporate governance in their annual reports. It is also observed that among the sample IT companies, Infosys, Wipro, TCS and HCL scored high score i.e. more than 100 and Tech Mahindra and Mphasis scored low score i.e. less than 96 in corporate governance disclosure practices. In fact, Infosys reports have set a benchmark for the other corporate houses to follow in improving their standards of corporate governance with respect to quality, transparency, full disclosures and in-depth reporting. 
In the following sections of this paper disclosure with respect to different areas of corporate governance structures, processes, and practices are covered.

\section{Board Related Matters}

The board of directors plays an important role in corporate governance for the best interest of the company. The board is accountable to shareholders and should remain independent of management. The board of directors should have leadership, vision and independence in making decisions for the best interest of the company and all shareholders. The board should clearly separate its roles and responsibilities from those of management and monitor the company's operations to ensure that all activities are conducted in accordance with relevant laws and ethical standards.

The structure of the board should consist of directors with various qualifications, which are of skills, experience and expertise that are useful to the company. Directors should commit to their responsibilities and put all efforts to create a stronger board of directors.

For efficiency and effectiveness, the board of directors should set committees to study and screen special tasks on behalf of the board, especially issues that need unbiased opinions. Committees should have a clear scope of their work, roles and responsibilities as well as the working procedures such as meetings and reporting to the board [21].

Table 3 reveals the Board related matters in sample IT companies. It is observed that the F ratio for this data

Table 3. Board Related Matters in sample IT companies.

\begin{tabular}{cccccccc}
\hline Year & TCS & Infosys & Wipro & HCL & Tech M & Mphasis & Total Assigned Score \\
\hline $2004-05$ & $40(86.96)$ & $38(82.61)$ & $37(80.43)$ & $36(78.26)$ & $34(73.91)$ & $39(84.78)$ & $46(100.00)$ \\
$2005-06$ & $40(86.96)$ & $38(82.61)$ & $37(80.43)$ & $36(78.26)$ & $34(73.91)$ & $34(73.91)$ & $46(100.00)$ \\
$2006-07$ & $40(86.96)$ & $38(82.61)$ & $37(80.43)$ & $36(78.26)$ & $34(73.91)$ & $34(73.91)$ & $46(100.00)$ \\
$2007-08$ & $40(86.96)$ & $38(82.61)$ & $37(80.43)$ & $36(78.26)$ & $34(73.91)$ & $34(73.91)$ & $46(100.00)$ \\
$2008-09$ & $39(84.78)$ & $38(82.61)$ & $37(80.43)$ & $36(78.26)$ & $39(84.78)$ & $39(84.78)$ & $46(100.00)$ \\
$2009-10$ & $40(86.96)$ & $38(82.61)$ & $37(80.43)$ & $36(78.26)$ & $39(84.78)$ & $34(73.91)$ & $46(100.00)$ \\
$2010-11$ & $39(84.78)$ & $38(82.61)$ & $37(80.43)$ & $36(78.26)$ & $39(84.78)$ & $34(73.91)$ & $46(100.00)$ \\
$2011-12$ & $39(84.78)$ & $38(82.61)$ & $37(80.43)$ & $36(78.26)$ & $39(84.78)$ & $34(73.91)$ & $46(100.00)$ \\
\hline
\end{tabular}

Source: Researcher Compilation.

One-way ANOVA: TCS, Infosys, Wipro, HCL, Tech M, Mphasis.

\begin{tabular}{ccccc}
\hline Source & DOF & SS & MS & F Value \\
\hline Factor & 5 & 97.44 & 19.49 & 9.16 \\
Error & 42 & 89.37 & 2.13 & 0.00 \\
Total & 47 & 186.81 & & \\
\hline
\end{tabular}

$\mathrm{S}=1.459 \mathrm{R}-\mathrm{Sq}=52.16 \% \mathrm{R}-\mathrm{Sq}(\mathrm{adj})=46.46 \%$.

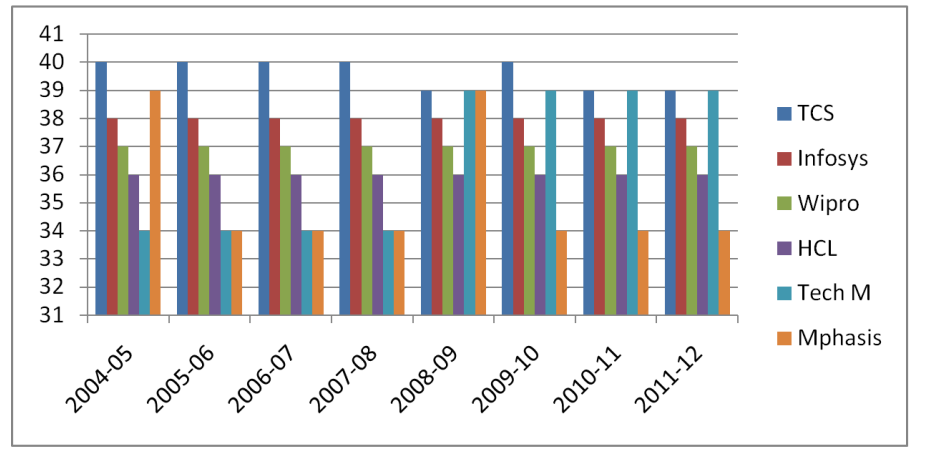


is 9.16 which not significant and P value is also zero. It gives the idea that the IT companies are behaving differently at Board related matters. The value of R-square is $52 \%$ and it indicates that there are some other factors which influence the Board related matters.

The board related matters in sample IT companies in the year 2004-05 were, 40 (86.96\%) 38 (82.61\%), 37 (80.43\%), 36 (78.26\%), 34 (73.91\%), 39 (84.78\%), in TCS, Infosys, Wipro, HCL, Tech Mahindra and Mphasis respectively. It is observed that the majority of the companies had a good board practices and, out of the 46 all the sample companies scored in between 34 and 40. At present the sample companies have scores of 39 (84.78\%), 38 (82.61\%), 37 (80.43\%), 36 (78.26\%), 39 (84.78\%), 34 (73.91\%) in TCS, Infosys, Wipro, HCL, Tech Mahindra and Mphasis respectively. It is found that all the sample companies are disclosing effectively the information relating to the frequency of board meetings, aggregate board attendance of the board members, combination of directors (including independent directors), responsibilities of the board of directors and chairman responsibility with respect to the board proceedings, rotation of directors for directorship, training, role of company secretary and other related matters of the board for ensuring the good corporate governance practices towards the shareholders.

\subsection{Independence of the Board}

The Board of directors of the company shall have an optimum combination of executive and non-executive directors with not less than fifty percent of the board of directors comprising non-executive directors.

i. Where the Chairman of the Board is a non-executive director, at least one-third of the Board should comprise independent directors and in case he is an executive director, at least half of the Board should comprise independent directors. For the purpose of the sub-clause (i), the expression 'independent director' shall mean a non-executive director of the company who:

a) Apart from receiving director's remuneration, a director should not have any material pecuniary relationships or transactions with the company, its promoters, its directors, its senior management or its holding company, its subsidiaries and associates which may affect the independence of the director;

b) is not related to promoters or persons occupying management positions at the board level or at one level below the board;

c) Has not been an executive of the company in the immediately preceding three financial years;

d) is not a partner or an executive or was not partner or an executive during the preceding three years, of any of the following:

ii. The statutory audit firm or the internal audit firm that is associated with the company, and ii) the legal firm(s) and consulting firm(s) that have a material association with the company.

e) is not a material supplier, service provider or customer or a lessor or lessee of the company, which may affect the independence of the director; and is not a substantial shareholder of the company i.e. owning two percent or more of the block of voting shares [11].

Table 4 reveals the constituent of independent directors in the board. If the company had 1/2 of the board 5

Table 4. Independent directors constitute more than $1 / 2$ of the board wise sample IT companies.

\begin{tabular}{|c|c|c|c|c|c|c|}
\hline Year & TCS & Infosys & Wipro & HCL & Tech M & Mphasis \\
\hline 2004-05 & 5 & 5 & 5 & 5 & 0 & 5 \\
\hline 2005-06 & 5 & 5 & 5 & 5 & 0 & 0 \\
\hline 2006-07 & 5 & 5 & 5 & 5 & 0 & 0 \\
\hline 2007-08 & 5 & 5 & 5 & 5 & 0 & 0 \\
\hline 2008-09 & 5 & 5 & 5 & 5 & 5 & 5 \\
\hline 2009-10 & 5 & 5 & 5 & 5 & 5 & 0 \\
\hline 2010-11 & 5 & 5 & 5 & 5 & 5 & 0 \\
\hline 2011-12 & 5 & 5 & 5 & 5 & 5 & 0 \\
\hline
\end{tabular}

Source: Researcher Compilation 
score if not 0 score has been assigned to this question. It is observed that TCS, Infosys, Wipro and HCL companies had more than $1 / 2$ of the board independent, one company i.e., Tech Mahindra has been maintaining more than 1/2 of the board independent form the year 2008-09 onwards. It also found that the Mphasis company had maintained 1/2 of the board independent in the years 2004-05 and 2008-09.

\subsection{CE0-Chairman Separation}

The separation of the role of CEO and Chairman is increasingly seen quite important because of the central role that a board chairman plays in the effective functioning of the board and its oversight of management. It is observed that out of the 6 sample companies, only 2 companies have CEO-Chairman separation i.e. Infosys and Mphasis and in the remaining 4 companies, the same individual held the CEO and board chairman positions. The corporate governance principles demanded that there should be a clear division of responsibilities at the helm of the company, which should ensure a balance of power and authority such that no single individual has unfettered powers of decision.

\subsection{Disclosure of Directors' Details}

All the sample companies provided the complete list and short biographies of the board members from year 2004-05 to 2011-12.

\subsection{Frequency of the Board Meetings}

The entire sample companies disclosed accurately the number of board meetings held, dates for board meetings and where the meetings were held in detail in the annual reports of the companies from year 2004-05 to 201112.

\subsection{Attendance at Board Meetings}

All the sample companies disclosed the directors' attendance for board meetings. Although attendance at board meetings is only one of the indicators of a directors contribution to the company and does not show whether a director actually contributes actively to board discussions, international best practices suggest that this should be a standard corporate governance disclosure.

\section{Nomination Related Matters}

The nomination committee is responsible for setting the criteria and process of nominating board members and top executives, selecting qualified candidates according to the pre-determined criteria and process, and presenting the result to the board. Then, the board will present the results at the shareholders' meeting for election. For the committee to perform their duties transparently and independently, the majority of the committee members should be independent directors. The chairman of the committee should be an independent director. The chairman should not be either a chairman or a member of any committee to ensure the independence of the committee.

The Table 5 reveals the scores obtained by sample companies relating to the nomination matters. It is observed that $\mathrm{F}$ value is 21.05 which is highly insignificant. So the top six IT companies behave very differently and there is no uniformity among them in nomination matters. The high value of R-sq is $71 \%$ and it also supports that the ANOVA models better explain the variability in the data.

The nomination related matters in the sample IT companies in the year 2004-05 were $0(0.00 \%), 20(95.24 \%)$, 18 (85.71\%), 0 (0.00\%), 0 (0.00\%) and $0(0.00 \%)$ in TCS, Infosys, Wipro, HCL, Tech Mahindra and Mphasis respectively. It is observed that in this year out of the 6 companies only 2 i.e. Infosys and Wipro had the nomination committees and remaining companies did not set up the committee. It is found that 3 companies did set up nomination committees and disclosed the role and responsibilities of the committee members' in the years 2006-07, 2008-09 and 2011-12 in TCS, HCL and Tech Mahindra respectively. It is also found that Mphasis Company did not set up the nomination committee. It is pragmatic that Infosys has published nomination committee charter in detail and also a report of compliance duly signed and dated by the chairperson of the committee. The Wipro Company had set up Nomination and Corporate Governance Committee, thereby enlarging the 
Table 5. Nomination Matters in sample IT companies.

\begin{tabular}{cccccccc}
\hline Year & TCS & Infosys & Wipro & HCL & Tech M & Mphasis & Total assigned score \\
\hline $2004-05$ & $0(0.00)$ & $20(95.24)$ & $18(85.71)$ & $0(0.00)$ & $0(0.00)$ & $0(0.00)$ & $21(100.00)$ \\
$2005-06$ & $0(0.00)$ & $20(95.24)$ & $9(42.86)$ & $0(0.00)$ & $0(0.00)$ & $0(0.00)$ & $21(100.00)$ \\
$2006-07$ & $13(61.90)$ & $20(95.24)$ & $9(42.86)$ & $0(0.00)$ & $0(0.00)$ & $0(0.00)$ & $21(100.00)$ \\
$2007-08$ & $13(61.90)$ & $20(95.24)$ & $9(42.86)$ & $0(0.00)$ & $0(0.00)$ & $0(0.00)$ & $21(100.00)$ \\
$2008-09$ & $13(61.90)$ & $20(95.24)$ & $17(80.95)$ & $16(76.19)$ & $0(0.00)$ & $0(0.00)$ & $21(100.00)$ \\
$2009-10$ & $13(61.90)$ & $20(95.24)$ & $19(90.48)$ & $19(90.48)$ & $0(0.00)$ & $0(0.00)$ & $21(100.00)$ \\
$2010-11$ & $13(61.90)$ & $20(95.24)$ & $19(90.48)$ & $15(71.43)$ & $0(0.00)$ & $0(0.00)$ & $21(100.00)$ \\
$2011-12$ & $13(61.90)$ & $20(95.24)$ & $19(90.48)$ & $15(71.43)$ & $5(23.81)$ & $0(0.00)$ & $21(100.00)$ \\
\hline
\end{tabular}

Source: Researcher Compilation.

One-way ANOVA: TCS, Infosys, Wipro, HCL, Tech M, Mphasis.

\begin{tabular}{ccccc}
\hline Source & DOF & SS & MS & F value \\
\hline Factor & 5 & 2463.4 & 492.7 & 21.05 \\
Error & 42 & 983.1 & 23.4 & 0.000 \\
Total & 47 & 3446.5 & & \\
\hline
\end{tabular}

$\mathrm{S}=4.838 \mathrm{R}-\mathrm{Sq}=71.47 \% \mathrm{R}-\mathrm{Sq}(\mathrm{adj})=68.08 \%$

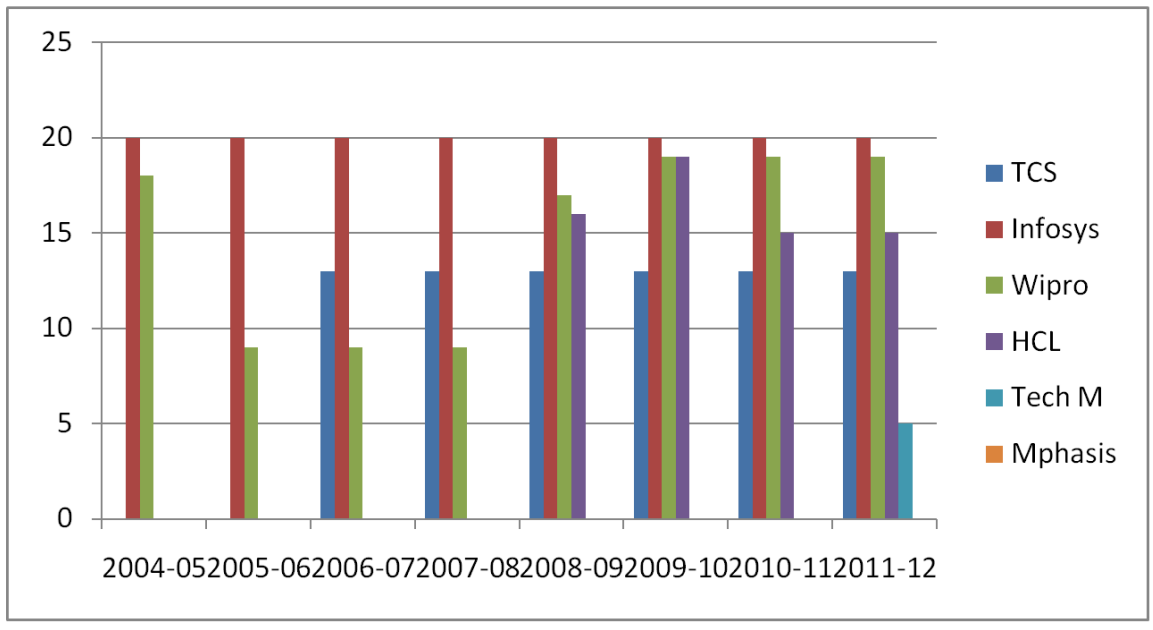

responsibility of governance compliance in addition to nomination responsibility.

\section{Remuneration Related Matters}

Remuneration committee is a very important committee. It deals with the matters relating to remuneration/compensation of the board members of a company. Therefore, a good corporate governance principle expects that adequate importance should be given for its formation, compliance of minimum requirement of the numbers of non-executive directors and appointment of an independent director as the chairman of the committee etc.

Table 6 reveals the remuneration matters of the sample IT companies. It is observed that an F value is 36.19 which is very highly insignificant. From this value, we can decide that there are significant differences between remuneration patterns. The high value of R-sq is $81 \%$ and it also supports that the ANOVA models is the best model for the data.

The remuneration matters of the sample companies in the year 2004-05 were 24(82.76\%), 26(89.66\%), 25 
Table 6. Remuneration Matters in sample IT companies.

\begin{tabular}{cccccccc}
\hline Year & TCS & Infosys & Wipro & HCL & Tech M & Mphasis & Total assigned score \\
\hline $2004-05$ & $24(82.76)$ & $26(89.66)$ & $25(86.21)$ & $24(82.76)$ & $22(75.86)$ & $21(72.41)$ & $29(100.00)$ \\
$2005-06$ & $24(82.76)$ & $26(89.66)$ & $25(86.21)$ & $24(82.76)$ & $22(75.86)$ & $21(72.41)$ & $29(100.00)$ \\
$2006-07$ & $24(82.76)$ & $26(89.66)$ & $25(86.21)$ & $24(82.76)$ & $22(75.86)$ & $24(82.76)$ & $29(100.00)$ \\
$2007-08$ & $24(82.76)$ & $26(89.66)$ & $25(86.21)$ & $24(82.76)$ & $22(75.86)$ & $24(82.76)$ & $29(100.00)$ \\
$2008-09$ & $23(79.31)$ & $26(89.66)$ & $25(86.21)$ & $24(82.76)$ & $22(75.86)$ & $21(72.41)$ & $29(100.00)$ \\
$2009-10$ & $25(86.21)$ & $26(89.66)$ & $25(86.21)$ & $24(82.76)$ & $22(75.86)$ & $21(72.41)$ & $29(100.00)$ \\
$2010-11$ & $25(86.21)$ & $26(89.66)$ & $25(86.21)$ & $24(82.76)$ & $22(75.86)$ & $24(82.76)$ & $29(100.00)$ \\
$2011-12$ & $24(82.76)$ & $26(89.66)$ & $25(86.21)$ & $24(82.76)$ & $22(75.86)$ & $24(82.76)$ & $29(100.00)$ \\
\hline
\end{tabular}

Source: Researcher Compilation.

One-way ANOVA: TCS, Infosys, Wipro, HCL, Tech M, Mphasis.

\begin{tabular}{ccccc}
\hline Source & DOF & SS & MS & F value \\
\hline Factor & 5 & 89.938 & 17.988 & 36.19 \\
Error & 42 & 20.875 & 0.497 & \\
Total & 47 & 110.813 & & \\
\hline
\end{tabular}

$\mathrm{S}=0.7050 \mathrm{R}-\mathrm{Sq}=81.16 \% \mathrm{R}-\mathrm{Sq}(\mathrm{adj})=78.92 \%$

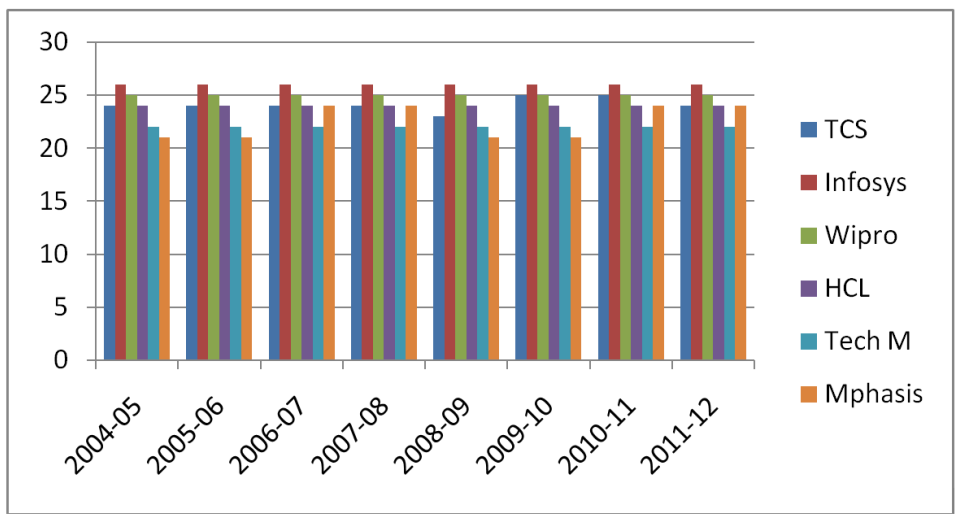

(86.21\%), 24 (82.76\%), 22 (75.86\%) and 21 (72.41\%) in TCS, Infosys, Wipro, HCL, Tech Mahindra and Mphasis respectively. it is found that the remuneration committee were set up by all the sample IT companies and disclosed the information relating to the frequency of the committee meetings, recommendations made to the board, remuneration committee process and disclosures of the remuneration given to the board of directors effectively for ensuring good corporate governance practices among the sample IT companies in India.

\subsection{Independence of the Remuneration Committee}

All the companies had remuneration committees and disclosed the names of the remuneration committee members and attendance. It is observed that out of the 6 sample IT companies 5 are had the remuneration committee made up of independent directors, while 1 company (Tech Mahindra) had a majority of independent directors on the remuneration committee.

\subsection{Disclosure of Directors Remuneration}

The entire sample companies disclosed the exact amounts received by the each executive director and non-ex- 
ecutive directors from the years 2004-05 to 2011-12.

\section{Audit Related Matters}

Audit committee, being one of the mandatory board committees, is the main pillar of corporate governance, the success or failure of which, largely depends upon the effectiveness of the audit committee functioning in the companies. There should be an adequate disclosure of audit committee charter and terms of reference in the annual report. Moreover, there should be clear transparency in the composition of audit committee, compliance regarding minimum number of independent directors in the committee, minimum requirement of number of committee meetings and information about literacy and expertise of committee members etc. The annual report should invariably publish the audit committee report.

In Table 7, it is observed that the F value is 25.85 which is very highly insignificant. From this value, we can decide that there are significant differences between audit related matters. The high values of R-sq is $75 \%$ and it also supports that the ANOVA model is the best model for the data.

The audit related matters of the sample IT companies in the year 2004-05 were 25(96.15\%), 25(96.15\%),

Table 7. Audit Related Matters in Sample IT Companies.

\begin{tabular}{cccccccc}
\hline Year & TCS & Infosys & Wipro & HCL & Tech M & Mphasis & Total assigned score \\
\hline $2004-05$ & $25(96.15)$ & $25(96.15)$ & $25(96.15)$ & $25(96.15)$ & $23(88.46)$ & $25(96.15)$ & $26(100.00)$ \\
$2005-06$ & $25(96.15)$ & $26(100.00)$ & $25(96.15)$ & $25(96.15)$ & $24(92.31)$ & $25(96.15)$ & $26(100.00)$ \\
$2006-07$ & $25(96.15)$ & $26(100.00)$ & $25(96.15)$ & $25(96.15)$ & $24(92.31)$ & $25(96.15)$ & $26(100.00)$ \\
$2007-08$ & $25(96.15)$ & $25(96.15)$ & $25(96.15)$ & $25(96.15)$ & $24(92.31)$ & $25(96.15)$ & $26(100.00)$ \\
$2008-09$ & $25(96.15)$ & $25(96.15)$ & $25(96.15)$ & $25(96.15)$ & $24(92.31)$ & $25(96.15)$ & $26(100.00)$ \\
$2009-10$ & $25(96.15)$ & $25(96.15)$ & $25(96.15)$ & $25(96.15)$ & $24(92.31)$ & $25(96.15)$ & $26(100.00)$ \\
$2010-11$ & $26(100.00)$ & $25(96.15)$ & $25(96.15)$ & $25(96.15)$ & $24(92.31)$ & $25(96.15)$ & $26(100.00)$ \\
$2011-12$ & $25(96.15)$ & $25(96.15)$ & $25(96.15)$ & $25(96.15)$ & $24(92.31)$ & $25(96.15)$ & $26(100.00)$ \\
\hline
\end{tabular}

Source: Researcher Compilation.

One-way ANOVA: TCS, Infosys, Wipro, HCL, Tech M, Mphasis.

\begin{tabular}{ccccc}
\hline Source & DOF & SS & MS & F value \\
\hline Factor & 5 & 10.000 & 2.000 & 25.85 \\
Error & 42 & 3.250 & 0.0774 & \\
Total & 47 & 13.250 & & \\
\hline
\end{tabular}

$\mathrm{S}=0.2782 \mathrm{R}-\mathrm{Sq}=75.47 \% \mathrm{R}-\mathrm{Sq}(\mathrm{adj})=72.55 \%$.

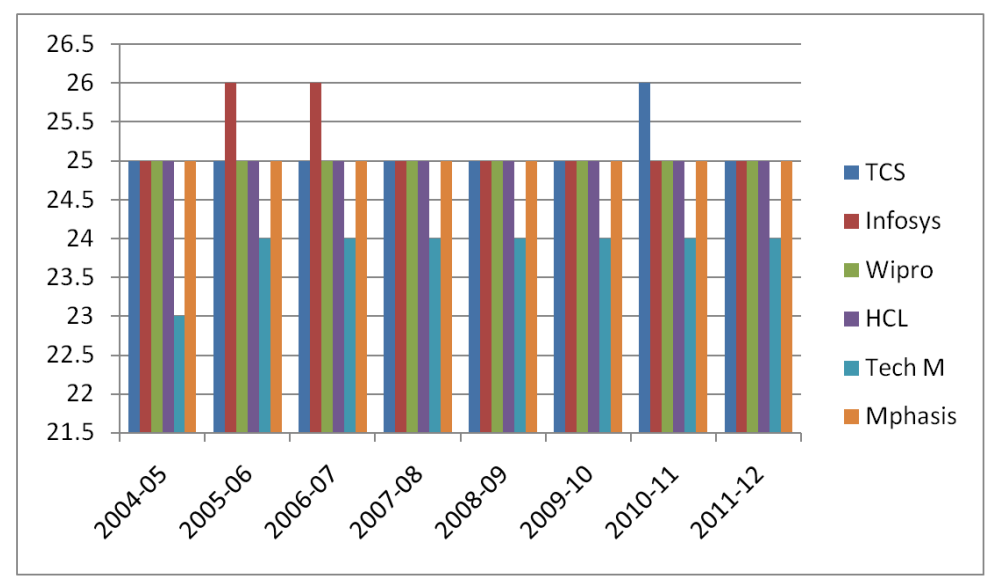


25(96.15\%), 25(96.15\%), 23(88.46\%) and 25(96.15\%) in TCS, Infosys, Wipro, HCL, Tech Mahindra and Mphasis respectively. It is observed that all the sample IT companies have been disclosing the audit related matters effectively for ensuring the good corporate governance. It is found that only 2 sample companies had a $100 \%$ attendance in audit committees in the years 2010-11 in TCS, 2005-06 and 2006-07 in Infosys. It is pragmatic that all the sample companies had more than $80 \%$ of attendance in the audit committee meetings.

\subsection{Independence of the Audit Committee}

The entire sample IT companies had a wholly independent audit committee, while one company (Tech Mahindra) had independent directors forming the majority of the audit committee form year 2004-05 to 2011-12.

\subsection{Frequency of Audit Committee Meetings}

All the sample IT companies is disclosed the frequency of the audit committee meetings from years 2004-05 to 2011-12.

\subsection{Attendance at Audit Committee Meetings}

The entire sample IT companies disclosed the attendance of individual members for the audit committee meetings. All the 6 sample companies reported $80 \%$ to $100 \%$ attendance. This is quite encouraging and it signals the high activity of the audit committees among the Indian companies men honed as the samples.

\section{Communication with Shareholders}

Disclosure and transparency are the uppermost cornerstones of corporate governance in any company. The effectiveness of the corporate governance principles and practices would depend upon stronger management information. The board of directors should ensure that all important information relevant to the company, both financial and non-financial is disclosed correctly and accurately and on a timely basis and also transparently through easy-to-access channels that are fair and trust worthy. Important company information includes financial reports and non-financial information specified in the regulations of the Securities and Exchange Board of India (SEBI) as well as any other relevant information such as the summary of the tasks of the board of directors and its committees during the year, corporate governance policy, environmental and social policies and the company's compliance with the above mentioned policies, etc. It is imperative for every corporate house to give full and transparent disclosures of all information relating to its business and performance on a real time basis.

Table 8 revelas that the communication with shareholders about the fiancial and non-fiancial information of the sample companies. It is observed that all the sample companies had a copy of their annual reports available to the public for viewing/dowloading on their web sites. The annual reports of the all companies were also avaiable on the Securites and Exchange Board of India web site.

Table 8. Communication in sample IT companies.

\begin{tabular}{cccccccc}
\hline Year & TCS & Infosys & Wipro & HCL & Tech M & Mphasis & Total assigned score \\
\hline $2004-05$ & $5(100.00)$ & $5(100.00)$ & $5(100.00)$ & $5(100.00)$ & $5(100.00)$ & $5(100.00)$ & $5(100.00)$ \\
$2005-06$ & $5(100.00)$ & $5(100.00)$ & $5(100.00)$ & $5(100.00)$ & $5(100.00)$ & $5(100.00)$ & $5(100.00)$ \\
$2006-07$ & $5(100.00)$ & $5(100.00)$ & $5(100.00)$ & $5(100.00)$ & $5(100.00)$ & $5(100.00)$ & $5(100.00)$ \\
$2007-08$ & $5(100.00)$ & $5(100.00)$ & $5(100.00)$ & $5(100.00)$ & $5(100.00)$ & $5(100.00)$ & $5(100.00)$ \\
$2008-09$ & $5(100.00)$ & $5(100.00)$ & $5(100.00)$ & $5(100.00)$ & $5(100.00)$ & $5(100.00)$ & $5(100.00)$ \\
$2009-10$ & $5(100.00)$ & $5(100.00)$ & $5(100.00)$ & $5(100.00)$ & $5(100.00)$ & $5(100.00)$ & $5(100.00)$ \\
$2010-11$ & $5(100.00)$ & $5(100.00)$ & $5(100.00)$ & $5(100.00)$ & $5(100.00)$ & $5(100.00)$ & $5(100.00)$ \\
$2011-12$ & $5(100.00)$ & $5(100.00)$ & $5(100.00)$ & $5(100.00)$ & $5(100.00)$ & $5(100.00)$ & $5(100.00)$ \\
\hline
\end{tabular}

Source: Researcher Compilation. 


\section{Conclusions}

In sum, to improve the usefulness of corporate governance disclosures, regulators could avoid requiring vague or overly-generalized information and work towards clarifying exactly what type of disclosures are required. For example, regulators can integrate within a corporate governance code an annual questionnaire that specially asks companies about their compliance with elements of the code. Similarly, regulators can issue a comprehensive listing of disclosure requirements to assist enterprises in preparing their report and help investors in understanding what information can be expected from companies. Both methods provide enterprises with detailed guidelines on specific corporate governance disclosure requirements and would remove any confusion among companies about what they are expected to report, as well as providing an easy reference point for investor and other stakeholders. Regulators could also consider implementing such things as annual disclosure questionnaires for forms through the internet and presenting the results of such disclosures in an orderly way via a searchable internet database. Such measures can increase the viability and a further facilitates investor access to corporate governance data.

In the present dynamic global market environment where there is a vast scope for corporate failures, appropriate measures should be adopted. In this context it is essential to follow global corporate governance disclosure standards which are well accepted bench marks for all corporate worlds. All the corporate companies must follow well enriched and universally accepted corporate governance standards and disclosure practices effectively and efficiently. Therefore, all the countries should make a serious effort for designing appropriate corporate governance mechanisms and disclosure practices. It is hoped that these measures would certainly go a long way in reshaping the corporate world. Ultimately it will reflect on strengthening the corporate performance, shareholders confidence, wealth maximization and consumer protection as well.

\section{References}

[1] Adhikari, A. and Tondkar, R. H. (1992) Environmental Factors Influencing Accounting Disclosure Requirements of Global Stock Exchanges. Journal of International Financial Management and Accounting, 4, 75-105. http://dx.doi.org/10.1111/j.1467-646X.1992.tb00024.x

[2] Cadbury Code (1992) The Report of the Committee on the Financial Aspects of CG: The Code of Best Practices. Gee Professional Publishing, London.

[3] Hampel Committee (1998) The Hampel Committee: Final Report. The European Corporate Governance Institute. www.ecgi.org/codes/documents/hampel.

[4] OECD Report (2006) The OECD Principle of Corporate Governance. The Organization for Economic Cooperation and Development, Paris.

[5] Whittington, G. (1993) Corporate Governance and the Regulation of Financial Reporting. Accounting and Business Research, 23, 311-319. http://dx.doi.org/10.1080/00014788.1993.9729899

[6] United Nations (2006) Guidance on Good Practices in Corporate Governance Disclosure. United Nations Conference on Trade and Development, Geneva, New York.

[7] Labelle (2002) The Statement of Corporate Governance Practices: A Voluntary Disclosure and Corporate Governance Perspective. HEC Montreal Working Paper.

[8] Patel, M. (2006) Inside Clause 49. Express Computer. www.expresscomputeronline.com

[9] Verma, S. K. and Gupta, S. (2004) Corporate Governance and Corporate Law Reform in India. Institute of Developing Economics—Japan External Trade Organization, Asian Law Series, Paper No. 25.

[10] Chakrabarti, R., Megginson, W. and Yadav, P. K. (2008) Corporate Governance in India. Journal of Applied Corporate Finance, 20, 59-72. http://dx.doi.org/10.1111/j.1745-6622.2008.00169.x

[11] SEBI: Clause 49 of the Listing Agreement, Issued by the Securities and Exchange Board of India. http://www.sebi.gov.in/

[12] Subramanian, S. (2006) Management Control and Differences in Disclosure Levels: The Indian Scenario. The ICFAI Journal of Corporate Governance, 5, 16-33.

[13] Nowland, J. (2008) The Effect of National Governance Codes on Firm Disclosure Practices: Evidence from Analyst Earnings Forecasts. Corporate Governance: An International Review, 16, 475-491.

[14] Bhasin, M.L. (2009) Corporate Governance Disclosure Practices: The Portrait of a Developing Country. International Journal of Business and Management, 5, 150-167. 
[15] Standrds \& Poors (2004) Corporate Governance Disclosures in Singapore: A Study of STI Companies.

[16] The Stock Exchange of Thailand (2006) The Principles of Good Corporate Governance for Listed Companies. 1-43.

[17] Black, B.S. (2009) Corporate Governance in Brazil, Working Paper. http://www.ssrn.com/

[18] Dessai, S.P.S. and Bhanumurthy, I. (2010) Corporate Governance and Disclosure Practices: A Study of Sensex (Index) Companies. http://www.ssrn.com/

[19] Sen, A. (2011) Corporate Governance in India: Clause 49 of the Listing Agreement. JM International Journal of Management Research, 1, 162-172.

[20] Patel, S. and Patel, R. (2012) Corporate Governance Practices in Information Technology Industry in India: A Comparative Analysis, Vol. 2, 1-8.

[21] Subramananan, B.N. (2009) Firm Level Corporate Governance in Emerging Markets: A Case Study of India, http://www.ssrn.com/ 


\section{Appendix}

Corporate Governance Disclosure Parameters of Sample IT Companies Appendix-I.

\begin{tabular}{|c|c|c|c|c|c|c|c|c|c|c|c|c|c|c|c|c|c|c|c|c|c|c|c|c|}
\hline \multirow{2}{*}{ Year } & \multicolumn{4}{|c|}{ TCS } & \multicolumn{4}{|c|}{ Infosys } & \multicolumn{4}{|c|}{ Wipro } & \multicolumn{4}{|c|}{ HCL } & \multicolumn{4}{|c|}{ Tech M } & \multicolumn{4}{|c|}{ Mphasis } \\
\hline & CG1 & CGD2 & CG3 & CGD4 & CG1 & CGD2 & CGD3 & CGD4 & CGD1 & CGD2 & CGD3 & CGD4 & CGD1 & CGD2 & CGD3 & CGD4 & CGD1 & CGD2 & CGD3 & CGD4 & CGD1 & CGD2 & CG3 & CGD4 \\
\hline 2004-05 & 40 & 0 & 24 & 25 & 38 & 20 & 26 & 25 & 37 & 18 & 25 & 25 & 36 & 0 & 24 & 25 & 34 & 0 & 22 & 23 & 39 & 0 & 21 & 25 \\
\hline 2005-06 & 40 & 0 & 24 & 25 & 38 & 20 & 26 & 26 & 37 & 9 & 25 & 25 & 36 & 0 & 24 & 25 & 34 & 0 & 22 & 24 & 34 & 0 & 21 & 25 \\
\hline 2006-07 & 40 & 13 & 24 & 25 & 38 & 20 & 26 & 26 & 37 & 9 & 25 & 25 & 36 & 0 & 24 & 25 & 34 & 0 & 22 & 24 & 34 & 0 & 24 & 25 \\
\hline 2007-08 & 40 & 13 & 24 & 25 & 38 & 20 & 26 & 25 & 37 & 9 & 25 & 25 & 36 & 0 & 24 & 25 & 34 & 0 & 22 & 24 & 34 & 0 & 24 & 25 \\
\hline 2008-09 & 39 & 13 & 23 & 25 & 38 & 20 & 26 & 25 & 37 & 17 & 25 & 25 & 36 & 16 & 24 & 25 & 39 & 0 & 22 & 24 & 39 & 0 & 21 & 25 \\
\hline 2009-10 & 40 & 13 & 25 & 25 & 38 & 20 & 26 & 25 & 37 & 19 & 25 & 25 & 36 & 19 & 24 & 25 & 39 & 0 & 22 & 24 & 34 & 0 & 21 & 25 \\
\hline 2010-11 & 39 & 13 & 25 & 26 & 38 & 20 & 26 & 25 & 37 & 19 & 25 & 25 & 36 & 15 & 24 & 25 & 39 & 0 & 22 & 24 & 34 & 0 & 24 & 25 \\
\hline 2011-12 & 39 & 13 & 24 & 25 & 38 & 20 & 26 & 25 & 37 & 19 & 25 & 25 & 36 & 15 & 24 & 25 & 39 & 5 & 22 & 24 & 34 & 0 & 24 & 25 \\
\hline
\end{tabular}
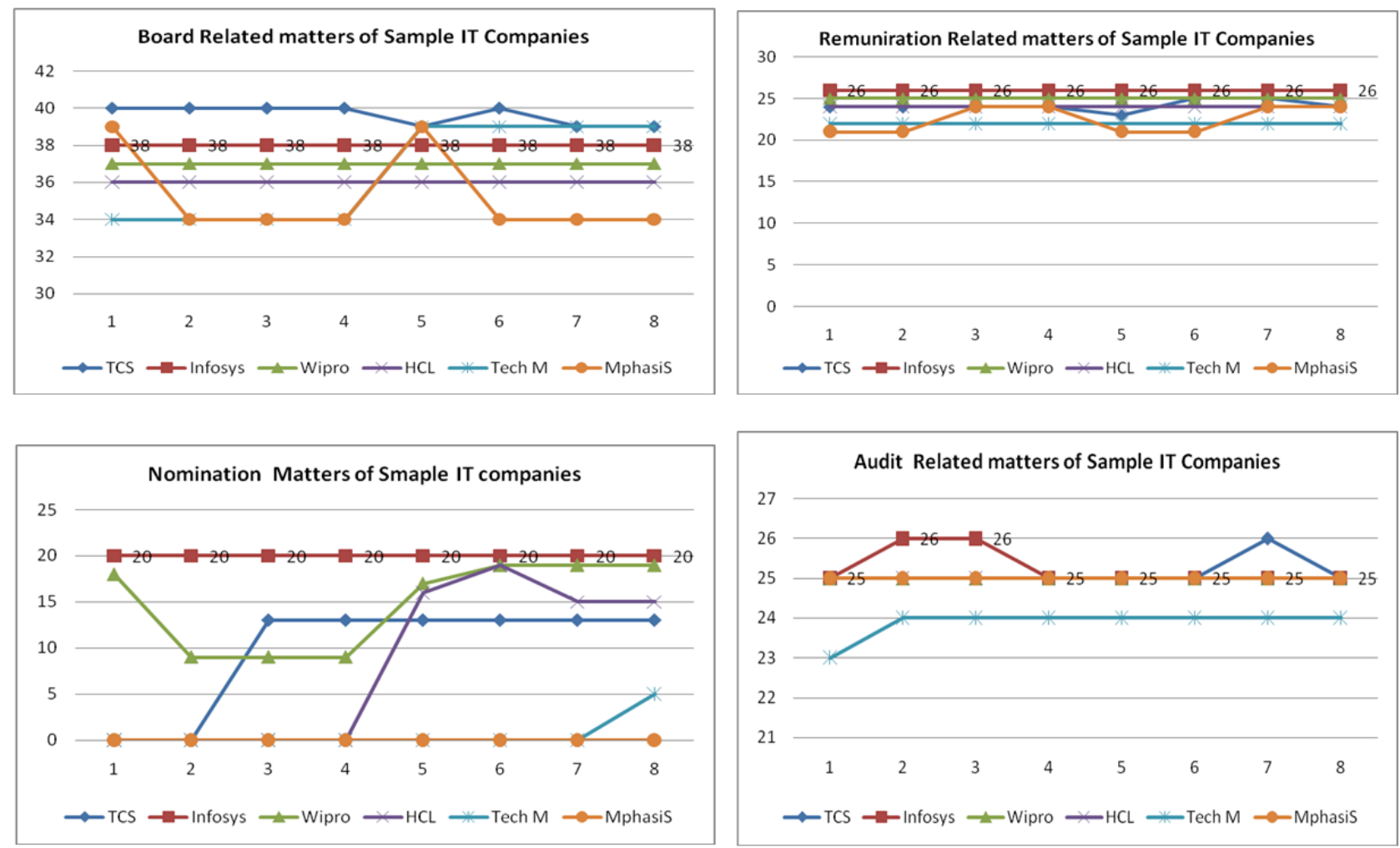

Analysis for CGD1: It is observed form the analysis that majority of the companies had a good board practices. Further it is also observed that out of 6 samples IT companies Infosys contributes more consistent and stable disclosures over the period of time. The average a disclosure of TCS is also exhibited moderate disclosures due to various reasons, but it is lacking consistency due to various reasons and other companies recorded very moderate disclosure efficiency in this regard.

Analysis for CGD2: The nominations matters of sample IT companies are displaying very interesting trend in terms of their disclosures. It is noticed that out of 6 sample companies the Infosys and Wipro had the nomination committees and the reaming did not set up the committees so far. It is also noticed that the companies who constituted nomination committees disclosed clearly the role and responsibilities of committee members, which is very essential aspect of corporate governance disclosures.

Analysis for CGD3: It is observed form the analysis that all the sample companies were established the remuneration committees and disclosed the information in detail ensuring good corporate governance and its disclosures in detail transparently.

Analysis for CGD4: The study reveals that all the sample companies had established audit committees and disclosed audit related matters effectively. It is noticed that all the companies have recorded a good disclosure practices during the period of study. 
Scientific Research Publishing (SCIRP) is one of the largest Open Access journal publishers. It is currently publishing more than 200 open access, online, peer-reviewed journals covering a wide range of academic disciplines. SCIRP serves the worldwide academic communities and contributes to the progress and application of science with its publication.

Other selected journals from SCIRP are listed as below. Submit your manuscript to us via either submit@scirp.org or Online Submission Portal.
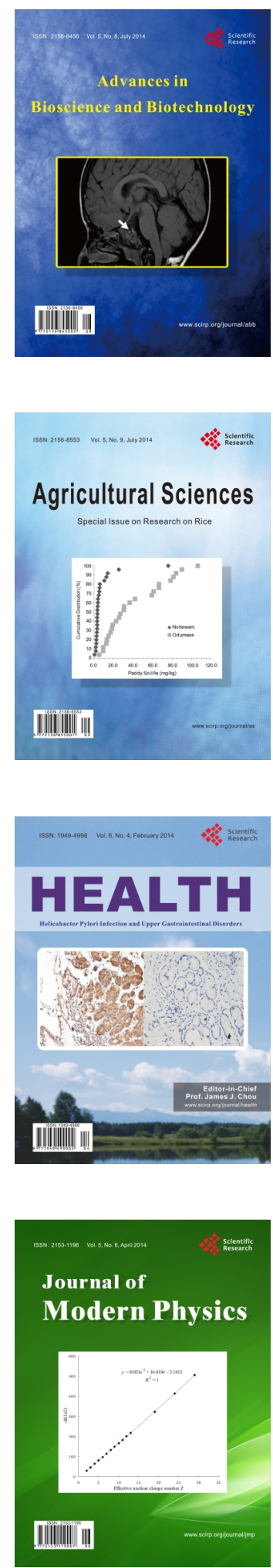
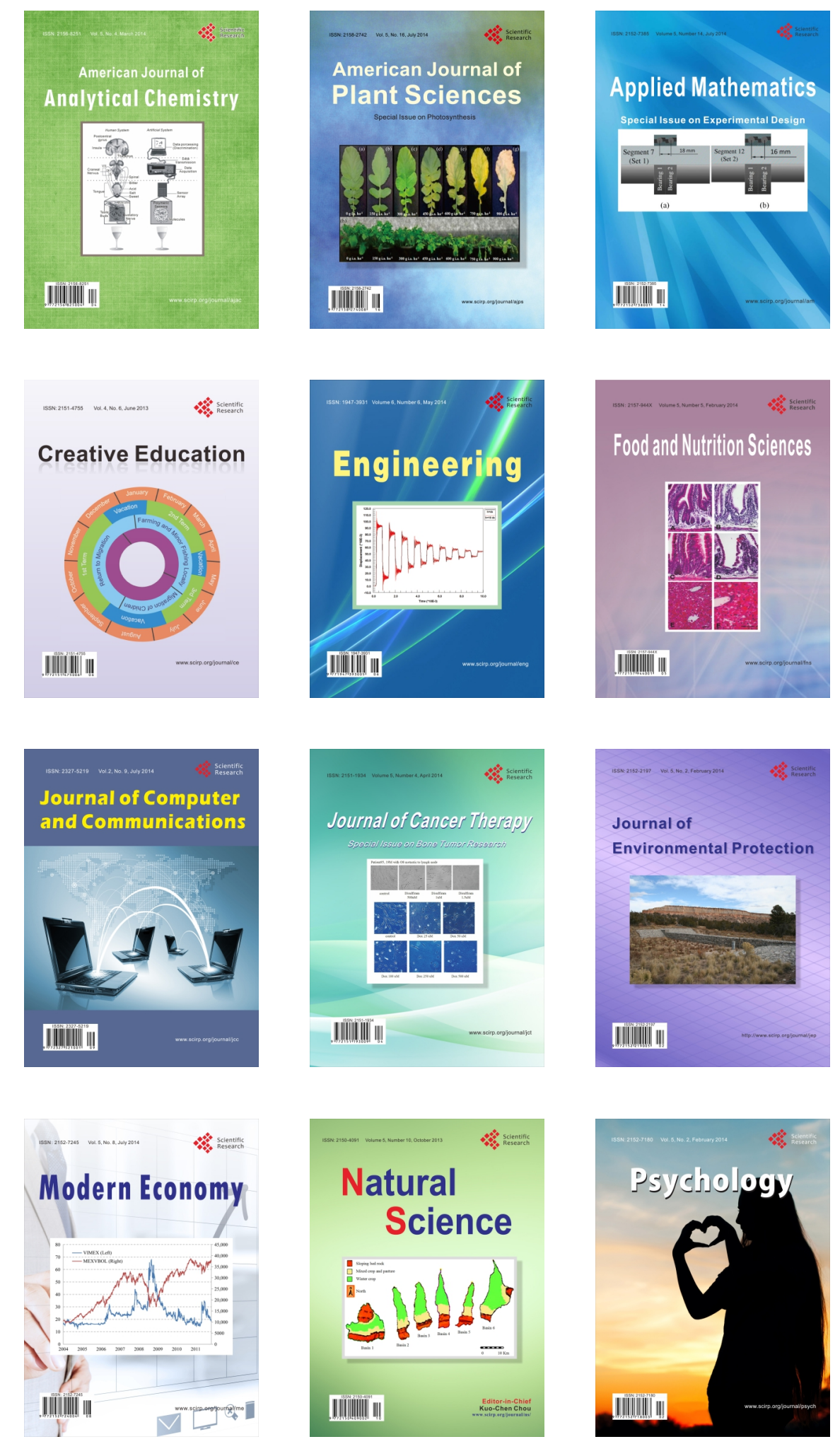